\title{
PENGEMBANGAN ALAT PERAGA PAPAN TURUNAN MATEMATIKA UNTUK MENINGKATKAN PEMAHAMAN KONSEP MATEMATIS SISWA SMA NEGERI 4 KEJURUAN MUDA
}

\author{
Widya Indriani $^{1)}$, Hayatun Nufus ${ }^{2)^{*}}$, Wulandari ${ }^{3)}$ \\ ${ }^{1,2,3}$ Program Studi Pendidikan Matematika, Universitas Malikussaleh, Aceh \\ *Korespondensi Penulis. E-mail: hayatun.nufus@unimal.ac.id
}

\begin{abstract}
Abstrak
Tujuan penelitian ini yaitu untuk menghasilkan media pembelajaran yaitu alat peraga papan turunan matematika pada materi turunan fungsi kelas XI, untuk mengetahui kevalidan media pembelajaran dan peningkatan pemahaman konsep matematis dengan berbantuan media pembelajaran yang telah dikembangkan. Metode yang digunakan adalah Research and Development (R\&D) dengan model pengembangan ADDIE yang meliputi lima tahap yaitu Analisys, Design, Development, Implementation, dan Evaluation. Kualitas alat peraga papan turunan matematika ditinjau dari aspek kevalidan dan peningkatkan pemahaman konsep matematis. Untuk aspek kevalidan diperoleh dari hasil penilaian 3 validator yaitu 2 orang ahli media memperoleh hasil persentase 78,24\% dengan kategori baik. 2 orang Ahli materi memperoleh hasil persentase $86 \%$ dengan kategori sangat baik. 5 Siswa kelompok kecil memperoleh hasil persentase $83,5 \%$ dengan kategori sangat baik. Rata-rata persentase dari ketiga validator adalah $82,63 \%$ dengan kategori sangat baik. Sedangkan untuk mengetahui peningkatan pemahaman knnsep matematis diperoleh dari pretest dan postest siswa kelompok besar dengan skor rata-rata pretest 43,3 dan skor rata-rata postest 84,3 sehingga N-Gain yang diperolah adalah 0,72 dengan interpretasi tinggi. Dari nilai N-Gain yang diperoleh maka alat peraga papan turunan dapat meningkatkan pemahaman konsep matematis siswa. Sehingga dapat disimpulkan bahwa alat peraga papan turunan matematika yang dikembangkan dinyatakan valid dapat meningkatkan pemahaman konsep matematis siswa.
\end{abstract}

Kata Kunci: Alat Peraga Papan Turunan Matematika, Media Pembelajaran, Pemahaman Konsep Matematis, Turunan Fungsi

\section{PENDAHULUAN}

Pemahaman konsep merupakan kemampuan yang berkenaan dengan memahami ideide matematika yang menyeluruh dan fungsional. Pemahaman konsep matematis siswa lebih penting daripada sekedar menghafal (Fahrudin, Achmad Gilang, Zuliana , \& Bintoro, 2018). Pemahaman konsep matematis siswa sangatlah penting bagi siswa, tidak hanya menghafal konsep saja namun harus memahami konsep tersebut. Belajar konsep merupakan hasil utama pendidikan dan merupakan landasan berpikir siswa untuk memecahkan suatu permsalahan pada teori yang dipelajari. Definisi lain pun diungkapkan oleh Gilbert (Iskandar, 2012), bahwa pemahaman konsep matematis adalah kemampuan menjelaskan suatu situasi dengan kata-kata yang berbeda dan dapat menginterpretasikan atau menarik kesimpulan dari tabel, data, grafik, dan sebagainya. Pada seorang siswa untuk memecahkan permasalahan dalam pembelajaran, siswa harus mengetahui aturan-aturan yang relevan yang diperoleh pada konsep-konsep. 


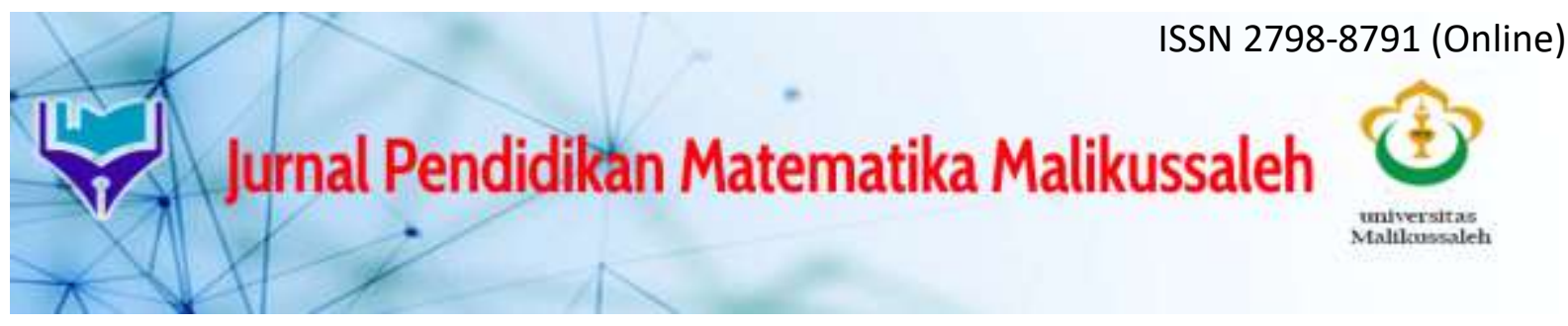

Volume 1, Nomor 2, November 2021

Berdasarkan hasil wawancara yang peneliti lakukan pada beberapa siswa kelas XI SMA Negeri 4 Kejuruan Muda, dapat disimpulkan mata pelajaran matematika merupakan pelajaran yang sulit dipahami. Salah satu materi yang dianggap sulit oleh siswa adalah turunan fungsi. Turunan fungsi sulit dipahami karena kurangnya pemahaman konsep dasar siswa pada turunan fungsi. Banyak faktor yang menyebabkan masih kurangnya pemahaman konsep matematis siswa di sekolah. Selain mewawancarai beberapa siswa kelas XI peneliti melakukan observasi dengan memberikan soal matematika dengan indikator pemahaman konsep. Berikut merupakan jawaban salah satu siswa:

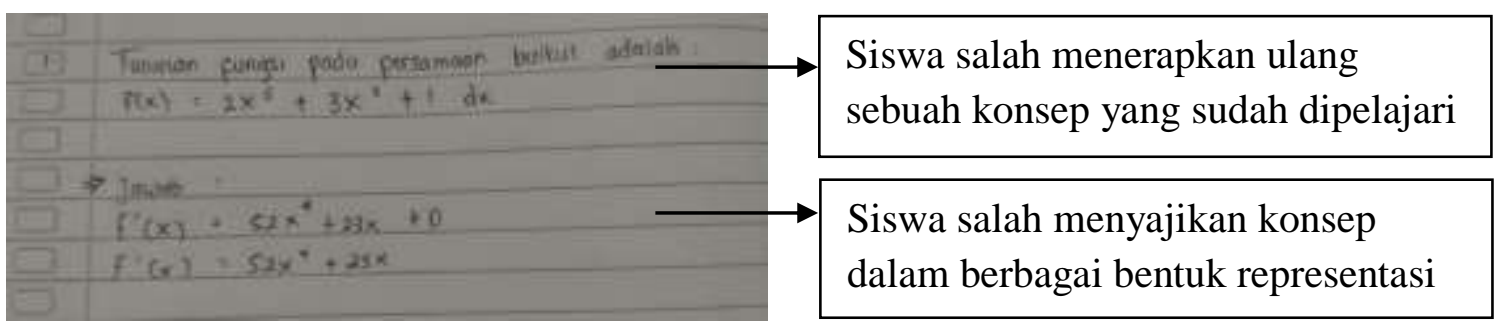

Gambar 1. Contoh Jawaban Siswa

Dari jawaban yang diberikan siswa di atas, siswa tidak dapat memenuhi ketiga indikator pemahaman konsep. Siswa tidak dapat menerapkan ulang sebuah konsep yang sudah dipelajari, siswa tidak dapat menyajikan konsep dalam berbagai bentuk representasi dan siswa tidak dapat mengaplikasikan konsep atau algoritma dalam pemecahan masalah. Sehingga dari jawaban yang diberikan di atas peneliti dapat melihat bahwas pemahaman konsep matematis siswa masih kurang. Untuk memahami pembelajaran matematika yang bersifat abstrak maka dibutuhkan alat bantu berupa media atau alat peraga yang dapat membantu siswa untuk memperjelas pemahaman konsep yang disampaikan oleh guru.

Di dalam pembelajaran matematika masih dibutuhkan benda-benda perantara sebagai alat peraga yang berfungsi untuk menyatakan fakta-fakta agar lebih jelas dan lebih dipahami oleh siswa (Nahdiyah, 2020). Alat peraga membantu siswa untuk memahami materi dengan lebih cepat dan mengerti konsep. Dengan demikian alat peraga sangat dibutuhkan dalam pembelajaran matematika. Alat peraga yang berfungsi untuk mengkonkretkan sehingga faktanya lebih jelas dan lebih mudah diterima siswa. Menurut (Yohanes, 2020) alat peraga matematika merupakan media pembelajaran yang dapat membantu siswa dalam mengkonkretkan konsep yang abstrak sehingga menjadi mudah untuk dipahami. Berdasarkan hal tersebut, untuk memahami suatu konsep matematika, siswa harus diberikan rangkaian kegiatan nyata yang dapat diterima akal mereka.

Berdasarkan hasil wawancara dengan salah satu guru matematika SMA Negeri 4 Kejuruan Muda diperoleh bahwa secara umum pembelajaran matematika yang dilaksanakan di sekolah masih menggunakan metode konvensional, yaitu ceramah, tanya jawab, serta penugasan. Pembelajaran matematika, khususnya pada materi turunan fungsi belum menggunakan alat peraga untuk membantu siswa dalam memahami materi pelajaran. Sehingga siswa kurang aktif dalam proses pembelajaran. Berkaitan dengan hal tersebut peneliti ingin mengembangkan suatu alat peraga yang dapat membantu siswa dalam memahami konsep matematika dan diharapkan mampu menarik perhatian dan keaktifan siswa dalam pembelajaran yaitu pengembangan alat peraga papan turunan matematika. 


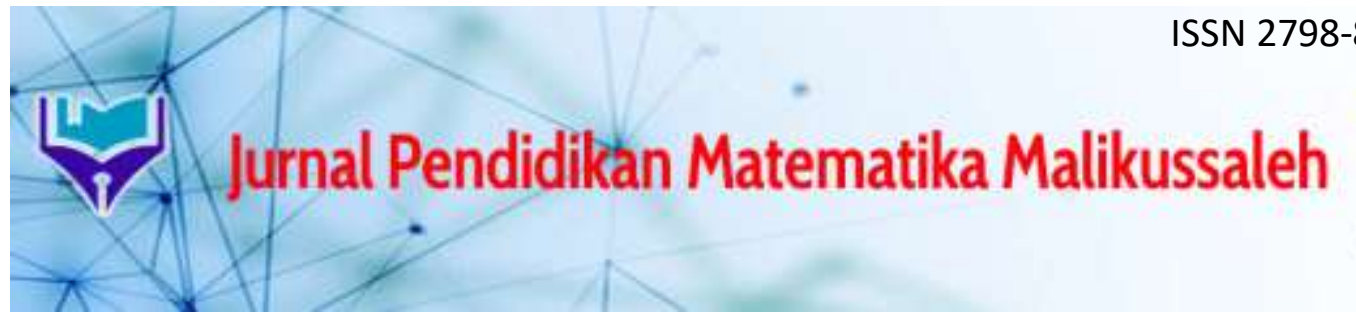

\section{Volume 1, Nomor 2, November 2021}

Pernyataan di atas diperkuat dengan adanya penelitian yang dilakukan oleh peneliti terdahulu yaitu penelitian (Aji, 2016) menunjukkan hasil kemampuan pemahaman konsep matematika siswa setelah diterapkannya pengembangan alat peraga matematika lebih baik dibandingkan kemampuan pemahaman konsep dengan pembelajaran konvensional. Penelitian yang dilakukan (Lismareni, 2018) juga menunjukkan bahwa penggunaan alat peraga papan turunan efektif terhadap hasil belajar matematika pada materi turunan di kelas XI SMA Negeri 1 Pajar Bulan tahun pelajaran 2017/2018. Demikian juga penelitian yang dilakukan oleh (Anjelita, 2019) menunjukkan bahwa penggunaan alat peraga blok pecahan dapat meningkatkan pemahaman konsep siswa di kelas III-B MIS Lamgugob Banda Aceh. Selanjutnya penelitian (Wahyudi, 2020) menunjukkan hasil bahwa alat peraga papan perkalian berbasis Montessori dapat membantu untuk memahami konsep perkalian.

Berdasarkan dari latar belakang masalah di atas penulis melakukan penelitian yang berjudul "Pengembangan alat peraga papan turunan matematika untuk meningkatkan pemahaman konsep matematis siswa SMA Negeri 4 Kejuruan Muda".

\section{METODE}

\section{Jenis Penelitian}

Peneliti menggunakan jenis penelitian dan pengembangan atau lebih dikenal dengan jenis penelitian R\&D (Research and Development). Menurut (Sugiyono, 2018), penelitian dan pengembangan merupakan metode penelitian yang digunakan untuk menghasilkan produk tertentu, dan menguji keefektifan produk tersebut. Dalam bidang pendidikan, metode ini dapat digunakan untuk mengembangkan buku, modul, media pembelajaran, instrumen evaluasi, model kurikulum, dan lain-lain (Hamdi, 2014). Penelitian jenis ini berbeda dengan penelitian pendidikan lainnya karena tujuannya adalah mengembangkan produk berdasarkan uji coba untuk kemudian direvisi sampai menghasilkan produk yang layak pakai. Model pengembangan yang digunakan dalam penelitian ini adalah model ADDIE (Analysis, Design, Development, Implementation, and Evaluation).

\section{Waktu dan Tempat Penelitian}

Tempat penelitian untuk pengembangan alat peraga papan turunan matematika ini adalah di SMAN 4 Kejuruan Muda yang beralamat di Kecamatan Kejuruan Muda, Kabupaten Aceh Tamiang, Provinsi Aceh. Penelitian dilaksanakan pada semester genap di tahun ajaran 2020/2021 pada bulan Mei 2021.

\section{Subjek dan Objek Penelitian}

Subjek dalam penelitian ini adalah Siswa Kelas XI SMA Negeri 4 Kejuruan Muda, Aceh Tamiang. Adapun yang menjadi objek dalam penelitian ini adalah kemampuan pemahaman konsep matematik siswa.

\section{Prosedur}

Model pengembangan yang digunakan dalam penelitian ini adalah model ADDIE (Analysis, Design, Development, Implementation, and Evaluation). Prosedur dalam pengembangan model ADDIE sebagai berikut: 


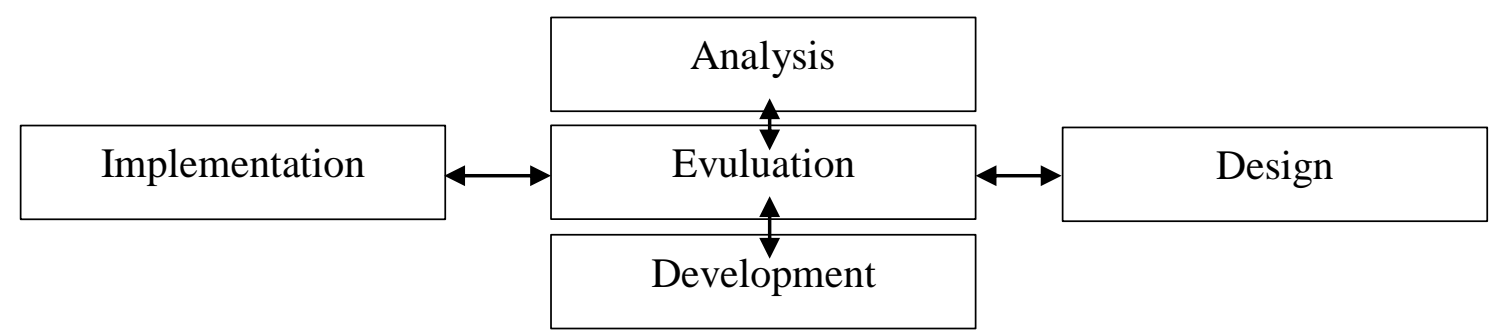

Gambar 2 Skema Model ADDIE

Sumber: (Sugiyono, 2018)

1. Analysis (Analisis)

Tahap pertama adalah analisis untuk mengetahui kebutuhan awal dalam mengembangkan alat peraga ini.

2. Design (Desain)

Tahap kedua adalah tahap pembuatan desain alat peraga yang akan dikembangkan. Tahap desain ini dilakukan dengan langkah-langkah sebagai berikut:

a. Ide desain alat peraga

b. Penentuan tujuan/konsep pembuatan alat peraga

c. Pemilihan bahan/pengumpulan bahan

d. Desain Instrumen

3. Development (Pengembangan dan Pembuatan Produk)

Tahap ini merupakan proses pembuatan alat peraga. Adapun tahap ini dibagi menjadi 3 tahap, yaitu:

a. Proses pengembangan alat peraga dari desain alat peraga

b. Proses pembuatan alat peraga

c. Tahap pengujian oleh validator

4. Implementation (Implementasi)

Alat peraga yang telah dikembangkan dan dinyatakan layak uji oleh dosen ahli media, dosen ahli materi dan guru matematika selanjutnya diimplementasikan kepada para peserta didik yang berjumlah 25 orang di kelas XI MIA 2 di SMA Negeri 4 Kejuruan Muda Kemudian para peserta didik mengisi angket evaluasi media.

5. Evaluation (Evaluasi)

Tahap evaluasi ini adalah tahap akhir dari pengembangan alat peraga yang dilakukan. Pada tahap ini peneliti melakukan evaluasi formatif dan evaluasi sumatif. Evaluasi formatif dilakukan dengan cara mengumpulkan data pada setiap tahapan yang digunakan untuk penyempurnaan alat peraga papan turunan matematika sedangkan evaluasi sumatif dilakukan pada akhir penelitian untuk mengetahui hasil dari pengembangan alat peraga papan turunan matematika.

\section{Data, Instrumen dan Teknik Pengumpulan Data}

Teknik pengumpulan data yang digunakan dalam penelitian ini adalah:

1. Tes

Instrumen tes untuk mengukur kemampuan dari pencapaian belajar berbentuk hasil balajar bahasa Indonesia dalam membaca.

2. Non-tes

Teknik pengumpulan data non-tes pada penelitian ini menggunakan angket. 


\section{universitas
Mallilussaleh}

\section{Volume 1, Nomor 2, November 2021}

Instrumen penelitian yang digunakan untuk mendapatkan data dari penelitian ini yakni meliputi :

a. Validasi Instrumen

Validasi instrumen tersebut mencakup tiga komponen yaitu:

a) Validasi Instrumen untuk Ahli Media

Validasi alat peraga dilakukan oleh salah seorang dosen Prodi Pendidikan Matematika Universitas Malikussaleh dan guru mata pelajaran matematika khususnya materi turunan fungsi di SMA Negeri 4 Kejuruan Muda.. Validasi ahli alat peraga ini bertujuan untuk melakukan uji kelayakan alat peraga yang dilihat dari aspek tampilan dan kegunaan.

b) Validasi Instrumen untuk Ahli Materi

Validasi materi dilakukan oleh salah seorang dosen Prodi Pendidikan Matematika Universitas Malikussakeh.

c) Validitas Instrumen untuk Kelompok Kecil

Validasi ini dilakukan oleh 5 siswa kelas XII di SMA Negeri 4 Kejuruan Muda.

Validasi ini bertujuan untuk melakukan uji kelayakan alat peraga.

b. Soal Tes

Tes perolehan hasil pembelajaran yang digunakan adalah dengan membandingkan hasil pretest dan posttest yang digunakan untuk menunjukkan peningkatan pemahaman konsep.

\section{Teknik Analisis Data}

Dalam penelitian ini terdapat dua macam data yaitu data kualitatif dan data kuantitatif. Analisis Data Kuantitatif

a. Analisis Data Hasil Angket

Penilaian angket menggunakan skala Likert $1-5$ disajikan pada tabel dibawah ini:

Tabel 1. Skala Likert

\begin{tabular}{|c|c|}
\hline Kategori & Skor \\
\hline Sangat layak & 5 \\
\hline Layak & 4 \\
\hline Cukup Layak & 3 \\
\hline Kurang Layak & 2 \\
\hline Sangat Kurang Layak & 1 \\
\hline
\end{tabular}

Sumber: (Sugiyono, 2018)

Skala penilaian yang diperoleh, dimasukkan kedalam tingkat kategori skala likert dengan rumus (Sugiyono, 2018)

Keterangan:

$$
\mathrm{P}_{\mathrm{k}}=\frac{S}{N} \times 100 \%
$$

$\mathrm{P}_{\mathrm{k}}$ : Nilai kategori skala kelayakan

$\mathrm{S}$ : Jumlah skor yang diperoleh

$\mathrm{N}$ : Jumlah skor ideal 


\section{Jurnal Pendidikan Matematika Malikussaleh} *

\section{Volume 1, Nomor 2, November 2021}

Tabel 2. Persentase hasil angket

\begin{tabular}{|c|c|c|}
\hline No. & Persentase (\%) & Kategori \\
\hline 1. & $x>80$ & Sangat Baik \\
\hline 2. & $60<x \leq 80$ & Baik \\
\hline 3. & $40<x \leq 60$ & Cukup \\
\hline 4. & $20<x \leq 40$ & Kurang \\
\hline 5. & $x \leq 20$ & Sangat Kurang \\
\hline
\end{tabular}

Sumber: (Widoyoko, 2012)

\section{b. Analisis Data Hasil Pre-test dan Post-test}

Analisis data yang diperoleh melalui lembar pre-test dan post-test untuk mengukur peningkatan kemampuan pemahaman konsep matematis siswa dianalisis dengan menggunakan normalized gain. Menurut Hake (Majdi, 2018), normalized gain dihitung menggunakan rumus sebagai berikut:

$$
\mathrm{G}=\frac{\text { Posttest average }- \text { Pretest average }}{100-\text { Pretest average }}
$$

Hasil perhitungan diinterpretasikan dengan menggunakan indeks gain (g) menurut klasifikasi Hake (Majdi, 2018) dapat dilihat pada tabel 3 berikut.

Tabel 3 interpretasi gain

\begin{tabular}{|c|c|}
\hline Indeks Gain & Interpretasi \\
\hline $\mathrm{g}>0,70$ & Tinggi \\
\hline $0,30<g \leq 0,70$ & Sedang \\
\hline $\mathrm{g} \leq 0,30$ & Rendah \\
\hline
\end{tabular}

Sumber: (Majdi, 2018)

2. Analisis Data Kualitatif

Data kualitatif diperoleh dari masukan, tanggapan, kritik dan saran perbaikan alat peraga papan turunan matematika oleh validator, kemudian dianalisis secara deskriptif kualitatif. Deskriptif kualitatif ialah melukiskan, menggambarkan, atau memaparkan keadaan objek yang diteliti apa adanya (Sugiyono, 2018).

\section{HASIL DAN PEMBAHASAN}

Penelitian ini mengembangkan sebuah produk berupa alat peraga papan turunan matematika dengan menggunakan model ADDIE yang memiliki 5 langkah yaitu analisi (Analysis), desain (Design), pengembangan (Development), implementasi (Implementation), dan evaluasi (Evaluation). Pada penelitian dan pengembangan ini bertujuan untuk mengetahui kelayakan alat peraga papan turunan matematika dan peningkatan pemahaman konsep matematis dengan berbantuan alat peraga papan turunan matematika.

\section{Hasil Validasi Ahli Media}

Hasil validasi ahli media diperoleh dari lembar validasi angket yang diisi oleh dua orang dosen Universitas Malikussaleh yang ahli dalam media pembelajaran. Adapun hasil validasi ahli media yang dapat dilihat pada tabel 4 


\section{Jurnal Pendidikan Matematika Malikussaleh} $x+10=10$

Volume 1, Nomor 2, November 2021

Tabel 4. Hasil Validasi Ahli Media

\begin{tabular}{|c|c|c|c|c|c|c|}
\hline \multirow{2}{*}{ No } & \multirow{2}{*}{ Aspek } & \multirow{2}{*}{$\begin{array}{l}\text { No } \\
\text { Butir }\end{array}$} & \multicolumn{2}{|c|}{ Validator } & \multirow{2}{*}{$\begin{array}{c}\text { Rata-rata }(\%) \\
\text { Per aspek }\end{array}$} & \multirow{2}{*}{ Kategori } \\
\hline & & & $\mathbf{I}$ & II & & \\
\hline \multirow{3}{*}{1} & \multirow{3}{*}{ Bahan Ajar } & 1 & 4 & 4 & \multirow{3}{*}{$83,33 \%$} & \multirow{3}{*}{ Sangat Baik } \\
\hline & & 2 & 4 & 4 & & \\
\hline & & 3 & 5 & 4 & & \\
\hline \multirow{2}{*}{2} & \multirow{2}{*}{ Pendidikan } & 4 & 5 & 5 & \multirow{2}{*}{$95 \%$} & \multirow{2}{*}{ Sangat Baik } \\
\hline & & 5 & 4 & 5 & & \\
\hline \multirow{5}{*}{3} & \multirow{5}{*}{ Daya Tahan } & 6 & 3 & 4 & \multirow{5}{*}{$66 \%$} & \multirow{5}{*}{ Baik } \\
\hline & & 7 & 3 & 3 & & \\
\hline & & 8 & 3 & 3 & & \\
\hline & & 9 & 3 & 2 & & \\
\hline & & 10 & 5 & 4 & & \\
\hline \multirow{3}{*}{4} & \multirow{3}{*}{ Efisien } & 11 & 5 & 4 & \multirow{3}{*}{$90 \%$} & \multirow{3}{*}{ Sangat Baik } \\
\hline & & 12 & 5 & 4 & & \\
\hline & & 13 & 5 & 4 & & \\
\hline \multirow{2}{*}{5} & \multirow{2}{*}{ Estetika } & 14 & 4 & 3 & \multirow{2}{*}{$60 \%$} & \multirow{2}{*}{ Cukup } \\
\hline & & 15 & 3 & 2 & & \\
\hline \multirow{2}{*}{6} & \multirow{2}{*}{$\begin{array}{l}\text { Bahan } \\
\text { Media }\end{array}$} & 16 & 5 & 5 & \multirow{2}{*}{$85 \%$} & \multirow{2}{*}{ Sangat Baik } \\
\hline & & 17 & 4 & 3 & & \\
\hline \multicolumn{3}{|c|}{ Rata-rata $(\%)$} & $82,35 \%$ & $74,12 \%$ & $78,24 \%$ & Baik \\
\hline
\end{tabular}

Berdasarkan tabel 4 , penilaian ahli media masing-masing validator yaitu validator I memperoleh hasil persentase $82,35 \%$ dengan kategori "Sangat Baik" dan validator II memperoleh hasil persentase 74,12\% dengan kategori "Baik". Rata-rata persentase dari kedua validator adalah 78,24\% dengan kategori "Baik". Dengan demikian alat peraga papan turunan matematika dinyatakan layak untuk digunakan dalam proses pembelajaran.

\section{Hasil Validasi Ahli Materi}

Validasi ahli materi oleh dua orang dosen Universitas Malikussaleh dan satu guru matematika di SMA Negeri 4 Kejuruan Muda bertujuan untuk melihat kelayakan alat peraga papan turunan matematika. Adapun hasil validasi ahli materi sebagai berikut.

Tabel 5 Hasil Validasi Ahli Materi

\begin{tabular}{|c|c|c|c|c|c|c|}
\hline \multirow{2}{*}{ No } & \multirow{2}{*}{ Aspek } & \multirow{2}{*}{$\begin{array}{l}\text { Nomor } \\
\text { Butir }\end{array}$} & \multicolumn{2}{|c|}{ Validator } & \multirow{2}{*}{$\begin{array}{c}\text { Rata-rata } \\
\text { (\%) Per } \\
\text { Aspek }\end{array}$} & \multirow{2}{*}{ Kategori } \\
\hline & & & I & II & & \\
\hline \multirow{3}{*}{1.} & \multirow{3}{*}{ Pembelajaran } & 1 & 4 & 5 & \multirow{3}{*}{$86,67 \%$} & \multirow{3}{*}{ Sangat Baik } \\
\hline & & 2 & 4 & 5 & & \\
\hline & & 3 & 4 & 4 & & \\
\hline \multirow{7}{*}{2.} & \multirow{7}{*}{ Pendidikan } & 4 & 4 & 5 & \multirow{7}{*}{$85,71 \%$} & \multirow{7}{*}{ Sangat Baik } \\
\hline & & 5 & 5 & 5 & & \\
\hline & & 6 & 4 & 5 & & \\
\hline & & 7 & 3 & 4 & & \\
\hline & & 8 & 3 & 5 & & \\
\hline & & 9 & 3 & 5 & & \\
\hline & & 10 & 5 & 4 & & \\
\hline \multicolumn{3}{|c|}{ Rata-rata (\%) } & $78 \%$ & $94 \%$ & $86 \%$ & Sangat Baik \\
\hline
\end{tabular}




\section{Volume 1, Nomor 2, November 2021}

Berdasarkan tabel 5, penilaian ahli materi masing-masing validator yaitu validator I memperoleh hasil persentase 78\% dengan kategori "Sangat Baik" dan validator II memperoleh hasil persentase 94\% dengan kategori "Sangat Baik". Rata-rata persentase dari kedua validator adalah 86\% dengan kategori "Sangat Baik". Dengan demikian alat peraga papan turunan matematika dinyatakan layak untuk digunakan dalam proses pembelajaran.

\section{Hasil validasi siswa kelompok kecil}

Hasil validasi ahli siswa kelompok kecil diperoleh dari lembar validasi angket yang diisi oleh lima orang siswa kelas XII SMA Negeri 4 Kejuruan Muda. Adapun hasil validasi ahli media yang dapat dilihat pada tabel 6 .

Tabel 6 Hasil Validasi Siswa Kelompok Kecil

\begin{tabular}{|c|c|c|c|c|c|c|c|c|c|}
\hline \multirow{2}{*}{ No } & \multirow{2}{*}{ Aspek } & \multirow{2}{*}{$\begin{array}{l}\text { Nomor } \\
\text { Butir }\end{array}$} & \multicolumn{5}{|c|}{ Validator } & \multirow{2}{*}{$\begin{array}{l}\text { Rata-rata } \\
\text { Per Aspek }\end{array}$} & \multirow{2}{*}{ Kategori } \\
\hline & & & I & II & III & IV & $\mathbf{V}$ & & \\
\hline \multirow{2}{*}{1.} & \multirow{2}{*}{ Efektifitas } & 1 & 4 & 4 & 4 & 4 & 4 & \multirow{2}{*}{$84 \%$} & \multirow{2}{*}{$\begin{array}{l}\text { Sangat } \\
\text { Baik }\end{array}$} \\
\hline & & 2 & 4 & 5 & 5 & 4 & 4 & & \\
\hline \multirow{2}{*}{2.} & \multirow{2}{*}{ Implementasi } & 3 & 4 & 5 & 5 & 5 & 4 & \multirow{2}{*}{$86 \%$} & \multirow{2}{*}{$\begin{array}{l}\text { Sangat } \\
\text { Baik }\end{array}$} \\
\hline & & 4 & 5 & 4 & 3 & 4 & 4 & & \\
\hline \multirow{2}{*}{3.} & \multirow{2}{*}{ Materi } & 5 & 4 & 3 & 3 & 5 & 4 & \multirow{2}{*}{$80 \%$} & \multirow{2}{*}{ Baik } \\
\hline & & 6 & 3 & 4 & 4 & 5 & 5 & & \\
\hline \multirow{2}{*}{4.} & \multirow{2}{*}{ Pembelajaran } & 7 & 4 & 5 & 5 & 5 & 4 & \multirow{2}{*}{$84 \%$} & \multirow{2}{*}{$\begin{array}{l}\text { Sangat } \\
\text { Baik }\end{array}$} \\
\hline & & 8 & 4 & 3 & 3 & 5 & 4 & & \\
\hline \multicolumn{3}{|c|}{ Rata-rata (\%) } & 80 & 82,5 & 80 & 92.5 & 82.5 & $83,5 \%$ & $\begin{array}{l}\text { Sangat } \\
\text { Baik }\end{array}$ \\
\hline
\end{tabular}

Berdasarkan tabel 6, penilaian siswa kelompok kecil masing-masing validator yaitu validator I memperoleh hasil persentase $80 \%$ dengan kategori "Baik". Validator II memperoleh hasil persentase $82,5 \%$ dengan kategori "Sangat Baik". Validator III memperoleh hasil persentase $80 \%$ dengan kategori "Baik". Validator IV memperoleh hail persentase 92,5\% dengan kategori "Sangat Baik". Validator V memperoleh hasil persentase $82,5 \%$ dengan kategori "Sangat Baik". Rata-rata persentase dari kelima validator adalah 83,5\% dengan kategori "Sangat Baik". Dengan demikian alat peraga papan turunan matematika dinyatakan layak untuk digunakan dalam proses pembelajaran.

1. Hasil Peningkatan Pemahaman Konsep Matematik Siswa

Data hasil peningkatan pemahaman konsep matematis dengan berbantuan alat peraga papan turunan matematika diperoleh dari nilai pretest dan postest dari siswa kelompok besar pada tahap implementasi. Nilai dari pretest dan postest digunakan untuk mengetahui peningkatan pemahaman konsep matematis dengan berbantuan alat peraga papan turunan matematika kelas XI pada materi turunan fungsi. Pemberian pretest dan postest dilakukan di kelas XI MIA 2 SMA Negeri 4 Kejuruan Muda dengan jumlah siswa 21 orang.

Berikut ini adalah data hasil perbandingan pretest dan postest per butir saoal siswa kelas XI MIA 2 SMA Negeri 4 Kejuruan Muda.akan disajikan dalam bentuk diagram batang berikut ini: 


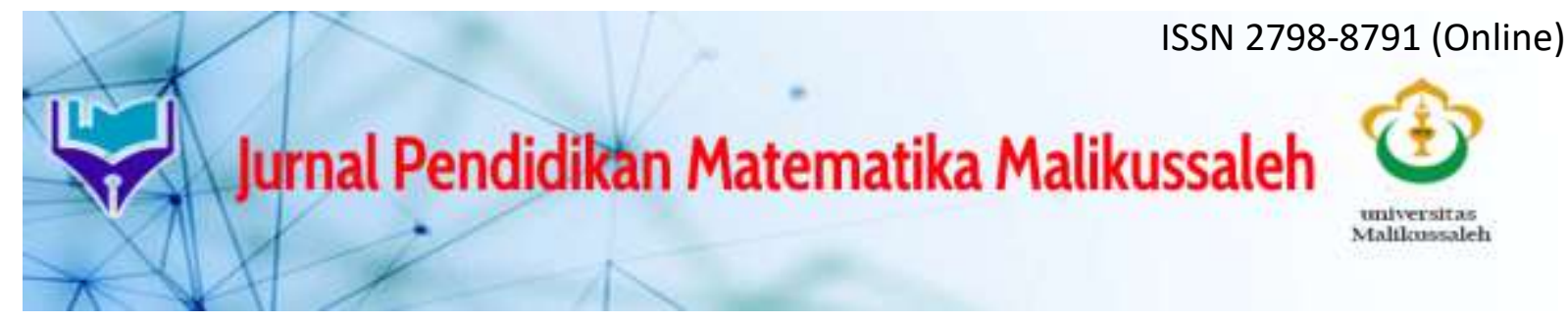

Volume 1, Nomor 2, November 2021

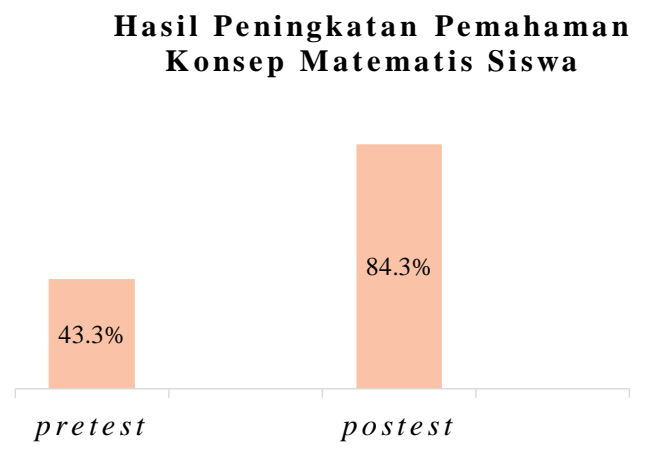

Gambar 3 Hasil Peningkatan Pemahaman Konsep Matematis Siswa

Berdasarkan gambar 3 di atas, nilai rata-rata dari hasil data pretest adalah 43,3 dan rata-rata hasil data postest adalah 84,3 sehingga menunjukan adanya peningkatan pemahaman konsep matematis. Dari rata-rata pretest dan postest akan dicari nilai $N$-Gainnya guna untuk menginterpretasikan peningkatan pemahaman konsep matematis. Berikut adalah perhitungan N-Gain:

$$
\begin{aligned}
\mathrm{G} & =\frac{\text { Posttest average-Pretest average }}{100-\text { Pretest average }} \\
& =\frac{84,3-43,3}{100-43,3}=\frac{41}{56,7}=0,72
\end{aligned}
$$

Berdasarkan hasil perhitungan $\mathrm{N}$-Gain di atas, perbandingan nilai pretest dan postest dalam proses pembelajaran berbantuan alat peraga papan turunan adalah 0,72 dengan interpretasi "Tinggi" sehingga dapat dikatakan adanya peningkatan pemahaman konsep matematis. Berdasarkan perhitungan perbandingan nilai rata-rata pretest dan postest dan perhitungan $\mathrm{N}$-Gain di atas, dapat disimpulkan alat peraga papan turunan matematika dapat meningkatkan pemahaman konsep matematis siswa.

\section{KESIMPULAN}

Berdasarkan hasil penelitian dan pengembangan yang telah dilaksanakan mengenai pengembangan alat peraga papan turunan matematika yang digunakan dalam proses pembelajaran untuk meningkatkan pemahaman konsep matematis siswa kelas XI MIA 2 SMA Negeri 4 kejuruan Muda pada materi turunan fungsi, maka dapat disimpulkan bahwa:

1. Alat peraga papan turunan matematika pada materi turunan yang dikembangkan layak untuk digunakan di kelas XI MIA 2 SMA Negeri 4 Kejurua Muda. Hasil kelayakan diperoleh berdasarkan hasil angket validasi alat peraga papan turunan matematika masing-masing validator yaitu ahli media memperoleh hasil persentase 78,24\% dengan kategori "Baik". Ahli materi memperoleh hasil persentase $86 \%$ dengan kategori "Sangat Baik". Siswa kelompok kecil memperoleh hasil persentase 83,5\% dengan kategori "Sangat Baik". Rata-rata persentase dari ketiga validator adalah 82,63\% dengan kategori "Sangat Baik". Dengan demikian alat peraga papan turunan matematika dinyatakan layak untuk digunakan dalam proses pembelajaran.

2. Alat peraga papan turunan matematika dapat meningkatkan pemahaman konsep matematis siswa kelas XI SMA Negeri 4 Kejuruan Muda pada materi turunan fungsi. Hasil ini berdasarkan hasil nilai rata-rata pretest adalah 43,3 dan rata-rata hasil data 


\section{Volume 1, Nomor 2, November 2021}

postest adalah 84,3 dan perhitungan $\mathrm{N}$-Gain adalah 0,72 dengan interpretasi "Tinggi" sehingga dapat dikatakan adanya peningkatan pemahaman konsep matematis.

\section{DAFTAR PUSTAKA}

Aji, V. G. (2016). Pengembangan Alat Peraga Penjumlahan Bersusun Matematika Untuk Meningkatkan Pemahaman Konsep Penjumlahan Siswa Sekolah Dasar . Yogyakarta: Skripsi: Universitas PGRI Yogyakarta.

Anjelita, R. (2019). Penggunaan Alat Peraga Blok Pecahan untuk Meningkatkan Pemahaman Konsep Siswa pada Materi Pecahan kelas III MIS Lamgugop Banda Aceh. Banda Aceh: Skripsi: Univesitas Islam Negeri AR-RANIRY.

Fahrudin, Achmad Gilang, Zuliana , E., \& Bintoro, H. S. (2018). Peningkatan pemahaman Konsep Matematika melalui Realistic Mathematic Education Berbantuan Alat Peraga Bongpas. Jurnal Ilmiah Pendidikan Matematika, 1(1): 15.

Hamdi, A. S. (2014). Metode Penelitian Kuantitatif Aplikasi dalam Pendidikan. Yogyakarta: Deepublish.

Iskandar, A. (2012). Peningkatan Kemampuan Pemahaman dan Komunikasi Matematika Siswa SD Melalui Pendekatan Realistic Mathrmatics Education. Seminar Nasional, FMIPA. Yogyakarta.

Lismareni, N. (2018). Efektivitas Alat Peraga Papan Turunan Terhadap Hasil Belajar Matematika Siswa Kelas XI. Jurnal Inovasi Pendidikan Matematika, Vol. 1 No. 1.

Majdi, M. K. (2018). Peningkatan Komunikasi Ilmiah Siswa SMA Melalui Model Quantum Learning One Day One Question Berbasis Dalily Life Science Question. Jurnal Pendidikan, Volume 1, No.1. Januari 2018: : 84.

Nahdiyah, F. (2020). Learning By Doing Media Belajar Jam Dinding Dalam Pembelajaran Matematika Di Sekolah Dasar. Jurnal Pendidikan, Volume 5 No. 2:191.

Sugiyono. (2018). Metode Penelitian Kuantitatif, Kualitatif dan R\&D . Bandung: Alfabeta.

Wahyudi, A. (2020). Pengembangan Alat Peraga Pembelajaran Matematika Materi Perkalian Berbasis Montessori. Jurnal ManajemenPendidikan, Volume 4 No. 2.

Widoyoko, E. P. (2012). Teknik Penyusunan Instrumen Penelitian . Yogyakarta: Pustaka Belajar.

Yohanes. (2020). Pemanfaatan Alat Peraga Matematika Sebagai Media Pembelajaran di SD Oebola Di Nusa Tenggara Timur . Jurnal abdidas, Volume 1 No. 5:339. 